\title{
IT\&C APPLICATIONS IN CABINETS OF ACCOUNTING EXPERTISE: THEORETICAL AND EMPIRICAL EXPLORATION
}

\author{
Florin Mihai ${ }^{l}$ \\ Bogdan Stefan Ionescu ${ }^{2}$ \\ Iuliana Mariana Ionescu ${ }^{3}$ \\ Laura Tudoran ${ }^{4}$
}

\begin{abstract}
In order to increase the performance, the companies are forced to find ways of becoming more efficient and also to develop the use of the new digital technologies so that the access, storage and transmission of information to be much easier and more accessible in terms of tariffs. The main objective of the research work was to identify the usability of the computer during the specific accounting activities by the master students attending professional or research master programs organized by the Faculty of Accounting and Management Information Systems from the Academy of Economic Studies that work as accountants. By means of a questionnaire distributed during January - April 2012, we intended to appreciate what kind of accounting software is used by the master students of the Faculty of Accounting and Management Information Systems with the aim of unfolding specific activities of the accounting profession, as well as, the usability of IT\&C technologies in their deployment.
\end{abstract}

Keywords : Cabinet of accounting expertise; Chartered accountant; IT\&C technologies; Accounting online software; Usability of IT technologies

Jel Code : M41

\section{Introduction}

The widespread use of IT technology caused major changes in organizations (K. V. Mgaya și E.G. Kitindi, 2008), still globalization and competitiveness require firms to find more efficient ways in order to develop them (IT), for obtaining competitive advantages and increasing performance, as well (G. Meşniţă, F. Dumitriu, 2006). The use of IT technology started with the automatizing of structured processes and reached up to use of the systems that revolutionizes the business fundamental processes (Gurbaxani și Whang, 1991).

According to the Sectorial Studies e-Business Watch, an integrated vision of using IT\&C technologies represents a crucial issue for understanding the implications of competitiveness of individual companies, both on fields of activity and economy-wide. Besides, the companies use IT\&C technologies (for various purposes and at different levels) and e-business for minimizing the costs and also maximizing their revenues.

At a basic level, the use of Internet and e-mail services do not have major implications as concerns the existing business, in fact, these virtual technologies sustain the existing processes with no need to change them. In view of more efficient use of business activities, such as the standardized data exchange with all business partners, the companies need to perform additionally some organizational changes. Those companies that offer financial advisory and tax belong to a field of activity that undergoes major changes, in main, due to the use of e-business components.

\footnotetext{
${ }^{1}$ The Bucharest University of Economic Studies, Romania, e-mail: fmihai@gmail.com

2 The Bucharest University of Economic Studies, Romania

${ }^{3}$ The Bucharest University of Economic Studies, Romania

${ }^{4}$ The Bucharest University of Economic Studies, Romania
} 
New digital technologies made possible that the access, storage and transmission of information to be much easier and more accessible as tariffs. As expected, IT\&C and e-Business models represent the most important factors of innovation and competitiveness (e-Business Guide for SME, 2008). In the same guide, Françoise Le Bail claimed that IT\&C will be able to provide substantial contributions in terms of productivity, only if there will be some organizational changes, such as innovative models of e-Business and investment in skills. The widespread use of IT has constrained the employees occupying important positions in the company management to endeavor of becoming more competent in using this modern technology (K. V. Mgaya și E.G. Kitindi, 2008). The computer is a productivity tool that is part of the working environment of accountants (Larres and Oyelere, 1999).

According to the report EITO 2007, the value of IT market in Romania was EUR 1.211 billion. The European average of IT expenses per inhabitant in 2005 was 614 Euro. Above the annual average were placed countries such as Great Britain (5th place with 1027 Euro), France (8th place with 888 Euro) and Germany (11th place with 797 Euro). Performance below average was obtained from countries like Italy (430 Euro) and Spain (326 Euro), followed by Portugal and Greece. The country with the highest value of IT expenses per inhabitant is Switzerland (1508 Euro), opposite hovering Romania with a value of 46 Euro.

IT\&C market value in Romania in million Euros is shown in the table below:

Table no. 1

IT\&C market value in Romania

\begin{tabular}{|l|r|r|r|r|r|}
\hline \multicolumn{1}{|c|}{ Romania } & $\mathbf{2 0 0 4}$ & $\mathbf{2 0 0 5}$ & $\mathbf{2 0 0 6}$ & $\mathbf{2 0 0 7}$ & $\mathbf{2 0 0 8}$ \\
\hline Servers & 73 & 86 & 86 & 97 & 107 \\
Workstations & 0 & 0 & 0 & 0 & 0 \\
PCs & 263 & 348 & 440 & 450 & 530 \\
Add-ons & 103 & 145 & 186 & 196 & 215 \\
\hline Computer Hardware & $\mathbf{4 3 9}$ & $\mathbf{5 8 0}$ & $\mathbf{7 1 3}$ & $\mathbf{7 4 3}$ & $\mathbf{8 5 3}$ \\
\hline Mobile phone sets & 195 & 220 & 246 & 290 & 312 \\
Other communications equipment for end-users & 75 & 73 & 72 & 72 & 71 \\
\hline Communications equipment for end-users & $\mathbf{2 7 0}$ & $\mathbf{2 9 4}$ & $\mathbf{3 1 8}$ & $\mathbf{3 6 3}$ & $\mathbf{3 8 3}$ \\
\hline Copiers & 22 & 23 & 24 & 24 & 23 \\
Other Office equipment & 24 & 26 & 28 & 30 & 31 \\
\hline Office equipment & $\mathbf{4 7}$ & $\mathbf{2 9}$ & $\mathbf{5 2}$ & $\mathbf{5 3}$ & $\mathbf{5 4}$ \\
\hline LAN hardware & 27 & 32 & 35 & 39 & 45 \\
PBX, key systems, etc. & 120 & 115 & 113 & 112 & 107 \\
Cellular mobile radio infrastructure & 204 & 207 & 209 & 212 & 215 \\
Packet switching and routing equipment & 48 & 53 & 59 & 66 & 71 \\
Other datacom and network equipment & 46 & 51 & 58 & 64 & 69 \\
\hline Datacom and network equipment & $\mathbf{4 4 5}$ & $\mathbf{4 5 9}$ & $\mathbf{4 7 5}$ & $\mathbf{4 9 3}$ & $\mathbf{5 0 8}$ \\
\hline Total ICT equipment & $\mathbf{1 2 0 0}$ & $\mathbf{1 3 8 2}$ & $\mathbf{1 5 5 8}$ & $\mathbf{1 6 5 2}$ & $\mathbf{1 7 9 8}$ \\
\hline System software & 46 & 54 & 61 & 67 & 73 \\
Application software & 54 & 63 & 72 & 80 & 89 \\
\hline Software products & $\mathbf{1 0 0}$ & $\mathbf{1 1 7}$ & $\mathbf{1 3 2}$ & $\mathbf{1 4 6}$ & $\mathbf{1 6 2}$ \\
\hline IT services & $\mathbf{1 3 5}$ & $\mathbf{1 6 1}$ & $\mathbf{1 9 1}$ & $\mathbf{2 2 4}$ & $\mathbf{2 5 9}$ \\
\hline Fixed voice telephone services & 540 & 552 & 563 & 568 & 562 \\
Fixed data services & 137 & 164 & 189 & 210 & 226 \\
& & &
\end{tabular}




\begin{tabular}{|l|r|r|r|r|r|}
\hline \multicolumn{1}{|c|}{ Romania } & $\mathbf{2 0 0 4}$ & $\mathbf{2 0 0 5}$ & $\mathbf{2 0 0 6}$ & $\mathbf{2 0 0 7}$ & $\mathbf{2 0 0 8}$ \\
\hline Mobile telephone services & 1060 & 1506 & 1869 & 2185 & 2444 \\
CaTV services & 217 & 241 & 265 & 289 & 312 \\
\hline Carrier services & $\mathbf{1 9 5 4}$ & $\mathbf{2 4 6 2}$ & $\mathbf{2 8 8 6}$ & $\mathbf{3 2 5 2}$ & $\mathbf{3 5 4 4}$ \\
\hline Total ICT & $\mathbf{3 3 9 0}$ & $\mathbf{4 1 2 2}$ & $\mathbf{4 7 6 7}$ & $\mathbf{5 2 7 4}$ & $\mathbf{5 7 6 3}$ \\
\hline Total IT & $\mathbf{8 1 8}$ & $\mathbf{1 0 1 8}$ & $\mathbf{1 2 1 1}$ & $\mathbf{1 3 0 3}$ & $\mathbf{1 4 7 9}$ \\
\hline Total telecommunications & $\mathbf{2 5 7 2}$ & $\mathbf{3 1 0 4}$ & $\mathbf{3 5 5 6}$ & $\mathbf{3 9 7 0}$ & $\mathbf{4 2 8 4}$ \\
\hline
\end{tabular}

Source: EITO Report, 2007

Whether for European companies web presence has become mandatory as it offers economic advantages, in Romania more than a third of companies have acquired a web domain. According to the report EITO of the European Commission, just 27\% of Romanian companies had a website in 2008, well below Bulgaria (33\%), Latvia (42\%), Portugal (46\%) and Hungary (46\%).

The situation in our country is diametrically opposed to that of the Netherlands and Finland, where companies were connected to the Internet up to $99 \%$ and most of them with websites. According to Eurostat, Romania was ranked on last place in January 2009 among European countries in terms of access to Internet companies. In January 2009, 93\% of European companies having 10 or more employees had Internet access (of which $82 \%$ have enjoyed a broadband-type connection), while in Romania just $72 \%$ of companies have benefited from internet connection (of which just $40 \%$ had a broadband-type connection). At present, it is relevant that of 22,078 accounting companies listed in the Yellow Pages, about 40\% (8832) do not have a website.

\section{Literature review}

Financial accounting function was the first area which has been computerized. Although computers have started to process the accounting data since the 50s, their initial impact on accounting profession was minimum, because the technology was not so sophisticated (K. V. Mgaya and E.G. Kitindi, 2008). Ledger and financial packages that have emerged on the market were just minor images of manual systems - accounting journals, trial balances, financial statements (Doost, 1999).

Dynamism and complexity of modern society makes the decision making process involves many risks (O. Aleca, 2005) . Accounting profession passes through a phase of substantial changes. Many changes in the business environment reveal uncertainties and concerns about the future of liberal accounting profession. Accounting activity is currently unfolding in a market increasingly saturated and competitive, but highly fragmented while maintaining the trend of international accounting convergence.

Major advances in IT led to the emergence of online systems in real time, database system management, networks, Internet, electronic data interchange (EDI), distributed processes, expert systems, and ERP systems (K. V. Mgaya and E.G. Kitindi, 2008). Through non-deterministic solutions and simple algorithms, artificial intelligence could become a base alternative for solving financial problems which require complex mathematic calculations or complex optimization (A. Cozgarea, G. Cozgarea \& A. Stanciu, 2008). In the period 2003-2008, technology they expected a major impact on financial reporting was Extensibile Business Reporting Language (Bovee et all 2002, Jones and Willis 2003, K. V. Mgaya and E.G. Kitindi, 2008), while now is definitely the cloud computing technology (which may have a significant impact on the accounting).

A few years ago, e-accounting was considered by all a new development direction in accounting computerization. On the other hand, if we add to e-accounting an Internet connection and a subscription to a virtual accounting service, we achieve a cloud accounting service. Unlike traditional accounting - where primary documents and records exist, in main, on paper - in e- 
accounting, source documents and accounting records are only in electronic format and that's why e-accounting was defined as an insertion of online technologies and Internet into bookkeeping.

Although the dematerialization of documents is not a short-term goal, however, a trend is emerging in this regard and the electronic management of documents is increasingly used by companies belonging to the tertiary sector. Many authors assesses that the opportunity provided of companies to dematerialize accounting documents represents a potential source of increasing the productivity and, consequently, a long-term strategic advantage.

Dematerialization of many accounting documents involves, in fact, a complete reorganization of the informational flow of electronic documents, with consequences on methods and evidence, respecting both rules in force and restrictions related to the archiving operation which must be accessible, integral and sustainable.

Besides, opening IT networks to the Internet requires a serious control of certain risks which they involve such an operation. Thus, the legal framework of dematerialization should allow to cover such risks and to compensate the loss of traditional means of identification, acceptance and preservation. Despite the advantages of this simple procedure in theory, the implementation procedure turns out to be quite difficult and elaborate, because is often difficult for any company to require its clients or suppliers all the restrictions related to dematerialization process.

\section{The main changes caused by IT\&C technologies in accounting}

Globally, the majority of chartered accountants have agreed in terms of the most important consequences of implementing IT\&C technology in accounting - increasing the degree of focus in large cabinets and, thus, opening up to competition, as well as, renewing of generations in the accounting profession:

- Degree of focus and opening up to competition - the small-sized cabinets of accounting expertise decide most of the times to merge with a view to reach a critical size required to achieve an efficient position on the market;

- Renewing of generations in the accounting profession - globally, grouping the chartered accountants by age categories describes a serious problem related to the renewal of generations in this profession. This situation is explained by the fact that although many young people follow accounting courses, very few choose to follow a career as chartered accountants. Nowadays, the general trend is to work in banking or multinational companies, this lack of attractiveness mainly affecting the small businesses. Despite this fact, a real challenge for accounting profession seems to loom. Organizing and equipping of the clients of accounting companies, actually, evolve very quickly, moreover, integration of IT\&C technologies seems necessary for anticipating and succeeding in business model of accounting expertise. As shown in the figure below, the interest in the accounting profession in Romania follows a downward trend, starting even with 2010.

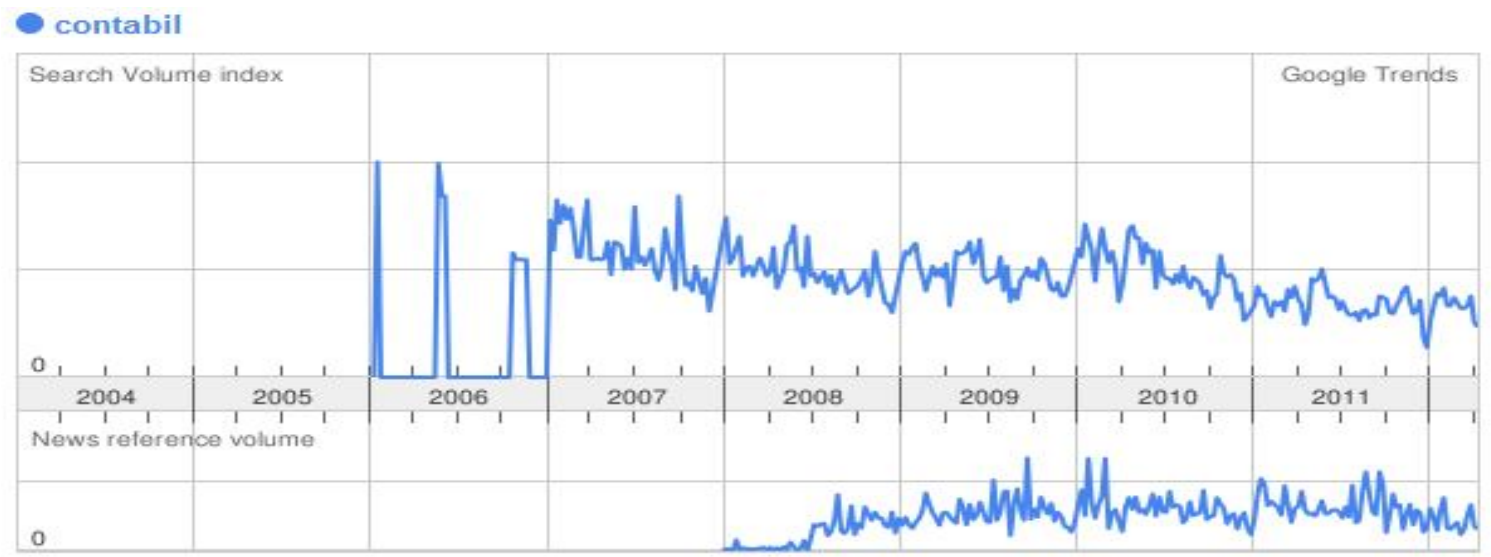

Figure no. 1 - The interest in the accounting profession in Romania (Google Trends, 2012) 


\section{The role of IT\&C technologies in relation to the accounting profession}

In the last few years, were noted three major roles of IT\&C in the accounting profession:

- Adaptation of the accounting profession to new informational technologies and development of a new electronic platform for the accounting profession, as well

Over the last years, the liberal accounting profession has been affected significantly by the technological developments. These particularly have encouraged the gradual emergence of the large cabinets or groups of cabinets with specific sectorial skills, provided with particular communication facilities. Moreover, these technologies have led to the reorganization of all the activities that can be digitized and therefore portable and accessible anywhere.

Eventually, the accounting companies are required to change their mentality related to their profession and, not least, how they operate, in terms of providing the best services to clients. The traditional chartered accountants must be replaced by a professional who can adapt continuously. IT\&C represents in this context a springboard for the accounting profession, as it should enable to simplify the accounting, tax and social tasks in order to well-understand and also develop the skills required. Furthermore, the use of IT\&C can help the companies to become acquainted on the market enabling, actually, a regular communication with their clients.

- Increasing the productivity of the cabinet of accounting expertise

Some technologies compounded with organizational methods can improve the cabinet productivity. This is the case of solutions having in view the dematerialization the accounting documents and exchange of information, electronic signature or use an ERP system. Practical application of a project referring to the dematerialization of accounting documents by the accounting profession is approachable all over the world and constitutes a real challenge for the small cabinets of accounting expertise. In fact, this project offers many opportunities, both in terms of cost and conditions of achieving the tasks and productivity, as well. Although this approach is pretty expensive, use an ERP system enables the automation of a large number of repetitive tasks, as well as, offers an additional service to the client.

- Ensuring the flexibility of the cabinet of accounting expertise

Solutions offering full Internet hosting are facing with a major increase and provide to clients online accounting services, with data synchronization between actors. These solutions offer new perspectives regarding the evolution of how to approach the tasks and, at the same time, the relationship with the clients (who often look for flexible and mobile management solutions).

The online services (SaaS) are currently used by an increasing number of cabinets. According to the supply, the software resources are hosted to the cabinet of accounting expertise or provider of hosted applications. The way of full hosting enables the equipping with solutions that facilitate remote access. Besides, some providers offer platforms for ensuring a proper collaboration between accounting companies and their clients. These electronic platforms facilitate anytime a secure data exchange that otherwise would be vulnerable on the Internet. Such solutions bring added value to any accounting cabinet and allow it to provide a number of innovative services.

The emergence of new technology for publishing of information leads to a significant evolution of concept "service". In a global economy, information represents the main economic resource because allow of anticipating the reactions of the market and concurrence. In this context, the modern economies have applied informational technology in order to automate both the dissemination and communication of information.

According to the national ethical code of professional accountants, "the principle of professional competence and prudence requires to all professional accountants to maintain the professional knowledge and skill on level required to ensure that a client or an employer will always receive competent professional service". According to the same code, maintaining the professional competence "requires understanding and knowledge of technical developments, professional and relevant business". 
Considering that the chartered accountant role is to contribute to the quality and output of accounting information for several years, they use applications more and more efficient. Also, many experts participate actively in the development of standards related to exchange of information.

Fekih K. (2006) has identified both the tools available to chartered accountants for their activities and tools available to collaborators of the cabinets of accounting expertise. In Fekih's opinion, development of new technologies, especially Internet technology, Intranet, Extranet, ASP ${ }^{1}$ propels the cabinets of accounting expertise to a new way of exercising of any accounting tasks and thus minimizing its costs and, implicit, the amount invoiced to clients.

These new technologies suggest the following solutions:

$\checkmark \quad$ A global solution for supporting the relationship between the cabinet of accounting expertise and client;

$\checkmark \quad$ A solution that has to be compatible with most IT environments and accounting applications used both by cabinets and clients;

$\checkmark \quad$ A private and secure solution that guarantees the integrity and confidentiality of information submitted.

Internet enables cabinets of accounting expertise with no major investments and company's personnel dedicated, regardless of the size and number of workstations to have a connection and an internal use that allow collaborators to work anywhere and anytime, perform remote folder revisions, exchange messages and documents, consult the agenda, access the basis for internal documentation, access and improve the informational basis, as well.

Using Extranet, the clients benefit from a set of online services, such as, the access to professional services with high security and remote assistance. A service as ASP enables to supplement the traditional accounting tasks by way of major innovations, but which requires the development of new control tools.

Those authors that developed several papers in IT systems scope should also measure the practical utility of ICT with the aid of various indicators. Schewe (1976) has used as indicator the number of information reports generated by the system, Thompson (2001) has used the duration of work sessions and frequency of computer use and Vezina (1995) has taken into account the variety, distribution and intensity of PC use.

As a result of a study performed over 283 accountants, T. Trigui (2009) found that they use the Internet daily at office, especially to improve the routine activity and, rarely, in an innovative way, fact that could offer clients new services. The same study found that Internet use in certain areas facilitates and also consolidates the relationships between accountant and his client, thus creating a feeling of virtual proximity between the two actors involved. Moreover, the study mentions also the disadvantages of using Internet, among which, depersonalization of the relationship between accountant and the client and, often, feeling of apartness felt on managerial level.

The study of T. Trigui and P. Chapellier (2009) revealed that the Internet represents an integral part of daily tasks carried in the cabinets of accounting expertise, but just a part of chartered accountants use it in an innovative manner in view of facilitating the collaboration, internal organization of cabinet, remote working or online accounting. Besides, this study pointed out that the Internet has improved certain aspects of the relationship between accountants and clients. Thus, the Internet has facilitated the access of the client to the chartered accountant by reducing the response time, exchanges almost "real-time" and higher availability, but also data access in terms of time and frequency.

\section{Research methodology}

The main objective of the research work was to identify the usability of the computer during the specific accounting activities by the master students enrolled in professional or research masters programs organized by the Faculty of Accounting and Management Information Systems from the 
Academy of Economic Studies and working in accounting. This research is closely related to a previous research by which we analyzed the hypothesis according to which a part of the accounting processing could be moved into the cloud using electronic platforms.

By means of such a questionnaire, we intend to appreciate what type of accounting software is used by the master students of the Faculty of Accounting and Management Information Systems in order to perform accounting related tasks and also the use (usability) of computers and of the Internet in the deployment of accounting tasks. The questionnaire was distributed during JanuaryApril 2012, both in electronic and traditional form to the master students registered at the Faculty of Accounting and Management Information Systems from the Academy of Economic Studies of Bucharest.

\section{Results}

After the initial processing of the statistical data obtained through the application of the interview technique, 223 usable responses have resulted from the master students who are attending professional or research master programs held by the Faculty of Accounting and Management Information Systems from the Academy of Economic Studies of Bucharest.

Of the 223 usable responses, $73.1 \%$ came from respondents who completed the degree studies at the Faculty of Accounting and Management Information Systems from the Academy of Economic Studies, 20.2\% came from respondents who graduated other universities with an ,accounting" specialization and $6.7 \%$ came from respondents who graduated universities without an ,accounting" specialization.

Out of the $38.6 \%$ of the respondents that work in the accounting area, $74.4 \%$ graduated the Faculty of Accounting and Management Information Systems, 22.1\% graduated other universities with an ,accounting" specialization and 3.5\% graduated other universities without an ,accounting” specialization.

In order to perform the accounting tasks required by their jobs, $79.1 \%$ of the respondents that work in this field are using traditional accounting software such as CIEL (19.8\%), Navision (1.2\%), Saga (45.3\%) or WinMentor $(12.8 \%)$. The remaining $20.9 \%$ of the respondents are using ERP. None of the respondents is using accounting software developed by them.

Over $40 \%$ of the respondents that work in the accounting field are using the "SAGA" accounting software. Deepening the study of the accounting software type used by the master students, we have discovered that over $30 \%$ of the respondents that graduated other faculties than the Faculty of Accounting and Management Information System are using the „CIEL" accounting software, as opposed to $12.5 \%$ of the respondents that graduated the Faculty of Accounting and Management Information System. Only $28.12 \%$ of the respondents who graduated the Faculty of Accounting and Management Information System are using ERP to perform accounting task. We can therefore notice a diversity of the type of accounting software used that is determined by the type of the faculty graduated.

When asked to appreciate the ease of use of the accounting software used to perform specific accounting tasks, more than half of the respondents stated that they have had experienced difficulties in using accounting software, while $47.7 \%$ stated that they have never experienced any difficulties while using accounting software.

The results obtained in the assessment phase of computer usage for a given set of circumstances are the following:

- Communication with the company's partners: over $60 \%$ of the respondents stated that they use the computer a lot to communicate with the company's partners. In this particular case, various options are available for the accountants: from a simple e-mail message to video conferences. There were no significant differences between the responses received from the three categories of respondents. 
- Storing documents: all the respondents stated that they use the computer very much for this purpose. Obviously, we are referring only to digital documents, since for our country the legal obligation of keeping the accounting records in a classic format is still present.

- Filling in tax or social returns: most of the respondents use very much the computer for filling in various tax or social forms, mainly because most accounting software create these forms automatically.

- Creating accounting documents: over $90 \%$ of the respondents have stated that they are using the computer very much in order to create several accounting documents.

- Automated management and computerized accounting: almost all the respondents stated that the management is automated and the accounting is computerized.

- Small processing of accounting documents: over $80 \%$ of the respondents have stated that they frequently use the computer in order to perform small processing of the accounting documents (such as quick value checks, quick counting of several other documents).

- Daily tasks received by e-mail: more than half of the respondents have stated that the daily tasks are sent by e-mail from their superiors.

The results obtained in the assessment phase of the utilization of the Internet (for work purposes only) for a given set of circumstances are:

- Information: $64 \%$ of the respondents use the Internet on a regular basis for work purposes, while $18.6 \%$ (which we consider a quite high percentage) do not use the Internet at all to gather work related information. We are excluding the possibility that our respondents have selected this latter answer option due to possible Internet access restrictions during the work schedule, because we were referring to the usage of Internet for general work purposes.

- E-mail: $33.7 \%$ of the respondents are not using the e-mail for work purposes, $9.3 \%$ are using the e-mail quite a lot, and $57 \%$ are using the e-mail on a daily basis for work purposes. These differences are caused by the lack or the presence of an internal e-mailing system of the accounting companies where they are working.

- Access to accounting forums: $5.8 \%$ of the respondents almost never access any accounting forums, $19.8 \%$ access accounting forums occasionally, $16.3 \%$ access the accounting forums once a day and $58.1 \%$ access the accounting forums more than once per day.

- On-line payments: A small percentage of $16 \%$ of the respondents stated that they never make on-line payments for work at the accounting company in which they work. Although the online payment method has become increasingly common in the past recent years, there are still many companies that prefer of performing various traditional payments.

- Updating the software: $18.6 \%$ of the respondents do not update their software using the Internet, while $81.4 \%$ update the software frequently from the Internet. The differences are caused by the type of software that needs to be updated and by the company structure (the existence or nonexistence of the IT personnel that handles the software updates).

- Accessing databases: $17.4 \%$ of the respondents have stated that they do not access databases, while $82.6 \%$ access them at different intensities and frequencies. In this case, the differences are caused by the personal IT capabilities.

- Remote working: $18.6 \%$ of the respondents have never worked remotely, $45.3 \%$ use this method rarely, $3.5 \%$ work remotely on rare occasions, $19.8 \%$ work remotely frequently and $12.8 \%$ work remotely almost daily.

\section{Conclusions}

The study performed by the research team and presented in this paper has identified the usability of computers and Internet during specific accounting activities. In fact, the 223 usable responses we received from master students that participate at professional or research master programs held by the Faculty of Accounting and Management Information Systems from the 
Academy of Economic Studies of Bucharest were analyzed using several statistical tests. The survey shows that accounting related tasks are now performed with a high rate of use of the computer and of the Internet, even if the majority of the master students that work in accounting are still using the traditional accounting software.

\section{References}

1. Aleca O., 2005. Inventory optimization through simulation, Journal of Accounting and Management Information Systems, No. 11-12, pp. 218-224

2. Bain C. E., Blankey A.I., Smith L. M., 2002. An examination of topical coverage for the first accounting information system course, Journal of Information Systems, Vol. 16, No. 2, pp $143-164$

3. Bovee M., Ettredge M. L., Srivastava R. P., Vasarhelyi M. A., 2002. Does the year 2000 XBRL taxonomy accomodate current business financial-reporting practice?, Journal of Information Systems, Vol. 16, No. 2, pp 165 - 182

4. Bromson G., Kaidonis M. A., Poh P., 1993. Accounting information systems and learning theory: an integrated approach to teaching, Accounting Education, Vol. 3, No. 2, pp 101 114

5. Brothick A. F., 1996. Helping accountants learn to get information managers want: the role of the accounting information systems course, Journal of Information Systems, Vol. 10, No. 2, pp $75-85$

6. Burnett S., 2003. The future of accounting education: a regional perspective, Journal of Education for Business, Vol. 78, No. 3, pp 129 -134

7. Caragea A., Gheorghiu R., Turlea G., 2003. Factors and impacts in the information society. A perspective analysis in the candidate countries - Report on Romania, Institute for Prospective Technological Studies

8. CECCAR, 2011. National Code of Ethics for Professional Accountants, CECCAR Publishing House, Bucharest,

9. Coy D., Grady W. O., 1992. The changing use of spreadsheets by accountants in New Zealand: a comparaison of 1991 to 1986, Journal of Information Systems, Vol. 6, No. 2, pp $171-181$

10. Cozgarea A., Cozgarea G., Stanciu A., 2008. Artificial intelligence applications in the financial sector, Theoretical and Applied Economics, vol. 12(517)(supplement), issue 12(517)(supplement), pp 57-62

11. Davis J. R., Leich R.A., 1988. Accounting information system courses and curricula: new perspectives, Journal of Information Systems, Vol. 3, No. 1, pp 153 -166

12. Doost R. K., 1999. Computers and accounting: where do we go from here?, Managerial Auditing Journal, Vol. 14, No. 9, pp 487 - 488

13. Edmonds T., 1988. A multidimensional assessment of practitioner perceptions regarding microcomputer course content, Issues in Accounting Education, Vol. 3, No. 1, pp 65 -71

14. European Commission, 2008. e-Business guide for SMEs. e-Business software and services in the european market, available online at http://ec.europa.eu/enterprise/e-bsn/ebusinesssolutions-guide/docs/eBusiness_Guide_for_SMEs.pdf, retrieved on 11/20/2011.

15. European Commission, 2008. European Information Technology Observatory - 2007

16. European Commission, 2010. ICT and e-Business for an innovative and sustainable economy, 7th Synthesis Report of the Sectoral e-Business Watch, pp. 22-25, available online at http://www.empirica.com/themen/ebusiness/documents/EBR09-10.pdf, retrieved on $12 / 10 / 2011$.

17. Fekih K., 2006. Le e-cabinet d expertise comptable, Le manager, no 84, pp 50-52

18. Gillet B., 2007. Un little Big Cabinet: Conseil Audit et Synthèse, La Profession Comptable, No. 292, available online 
http://www.laprofessioncomptable.com/pages/INTERVIEW/ConseilAuditSynthese.pdf, retrieved on $3 / 4 / 2012$

19. Gurbaxani V., Whang S., 1991. The impact of information systems on organizations and markets, Communications of the ACM, Vol. 34, No. 1, pp 59 - 73

20. Jones A., Willis M., 2003. The challenge of XBRL: business reporting for the investor, Balance Sheet, Vol. 11, No. 3, pp 29 -37

21. Johnson L. M., Johnson V. E., 1995. Help wanted - what the classifieds say about employer s expectations, Journal of Education for Business, Vol. 70, No. 3, pp 130-135

22. Larres P. M., Oyelere P., 1999. A critical analysis of self-assessment entry-level personal computer skills among newly qualified Irish chartered accountants, Accounting Education, Vol. 8, No. 3, pp 203- 216

23. Larres P. M., Ballantine J. A., Whittington M., 2003. Evaluating the validity of selfassessment: measuring computer literacy among entry-level undergraduates within accounting degree programs at two UK universities, Accounting Education, Vol. 12, No. 2, pp $97-112$

24. Meer G., Adams M., 1996. Accounting information system curriculum: an empirical analysis of the view of New Zealand-based accounting academics and practitioners, Accounting Education, Vol. 5, No. 4, pp 283 - 295

25. Meşniță G., Dumitriu F., 2005/2006. Caracteristicile pieței româneşti pentru externalizarea IT, Analele ştiințifice ale Universității Alexandru Ioan Cuza din Iaşi, Tomul LII/LII

26. Mgaya K. V., Kitindi E.G., 2008. IT skills of academics and practicing accountants in Botswana, World Review of Entrepreneurship, Management and Sustainable Development, vol 4, No. 4, pp 366-379

27. Patel J. K., 2011. Adoption and Impact of E-Accounting, Research Paper, Golden Resrach Thoughts, pp.1-4

28. Schewe C., 1976. The MIS User : An Exploratory Behavioral Analysis, Academy of Management Journal, Vol. 19, No. 4, p.577-590

29. Spitz J. C., 2003. L'expert comptable dans la petite entreprise, La lettre de 1 Observatoire consulaire des entreprises en difficulte, no. 22, juillet

30. Theuri P. M., Gunn R., 1998. Accounting information systems course structure and employer systems skills expectations, Journal of Accounting Education, Vol. 16, No. 1, pp $101-121$

31. Thomson R. L., Higgins C., Howell J.M., 1991. Personal computing: toward a conceptual model of utilisation, MIS Quartely, vol 15, No. 1

32. Trigui T., Chapellier P., 2009. L'Usage de l'Internet dans les petits et moyens cabinets d expertise comptable, Revue française de Comptabilité, no 424, septembre

33. Vézina M., 1995. L'impact de l'utilisation des technologies sur la performance: le cas des professionnels de la comptabilité, Thèse nouveau doctorat, Université Montpellier II

34. Wessels P. L., 2005. Critical information and communication technology skills for professional accountants, Meditari Accountancy Research, Vol. 13, No. 1, pp 87 - 103

35. ***, Les enjeux actuels des TIC dans les cabinets d'expertise comptable, 2008, available online at http://eduscol.education.fr/ecogest/si/cec/artcec, retrieved on 12/5/2011. 